\title{
FIDIC-OVI OPŠTI USLOVI UGOVORA I NJIHOVA PRIMENA NA DOMAĆEM TRŽIŠTU
}

\section{Ivan Nikčević}

Univerzitet Singidunum, Beograd, Srbija

\begin{abstract}
Apstrakt:
Polazeći od činjenice da od sredine prošlog veka gotovo da ne postoji značajniji građevinski poduhvat čiji ugovorni odnosi nisu regulisani FIDIC-ovim opštim uslovima ugovora, jasno je da su ti opšti uslovi, kroz dugogodišnju primenu, dokazali opštu prihvaćenost i značaj. Razlozi za to se mogu tražiti i na polju mnogobrojnih odnosa koji su njima regulisani, bilo da su oni tehničke, komercijlne ili pravne prirode, što učesnicima projekta omogućava da preuzmu "razrađen" odnos uzajamnih prava i obaveza. U prilog tome, rad sadrži analizu razvoja FIDIC-ovih opštih uslova ugovora, uz osvrt na specifičnosti njihove primene na domaćem tržištu.
\end{abstract}

Ključne reči:

opšti uslovi, inženjer, rešavanje sporova, arbitraža.

\section{UVOD}

U prvoj deceniji 21. veka Republika Srbija je širom otvorila vrata stranim investitorima. Jedna od značajnijih oblasti stranih investicija je oblast građevinarstva, koja svakodnevno dobija na značaju, kako zbog obaveze reformi infrastrukturnih sistema, tako i zbog prilagođavanja savremenim tehnološkim dostignućima i standardima u domenu industrijske proizvodnje. Statistika i razne analize pokazuju da domaće tržište, uz sve teškoće koje prate privrede zemalja u tranziciji, s jedne strane beleži poboljšanje, s druge strane potrebu daljeg unapređenja činilaca koji omogućavaju razvoj i investiciona ulaganja. Naime, u analizi "OECD indeks investicionih reformi u 2010. godini u Srbiji (IRI 2010)” je potvrđeno da je od 2006. godine naša država značajno unapredila većinu od sedam činilaca koji određuju investicionu klimu u regionu. Valjanost nekih činilaca ocenjena je najvišom ocenom, a još mora da se radi na poboljšanju zaštite prava intelektualne svojine i vlasništva, ubrzavanju izdavanja dozvola za rad i izgradnju, kao i omogućavanju strancima da postanu vlasnici lokacija za građenje (Unković, 2011).

U kontekstu navedenog, otvara se pitanje uslova koji će omogućiti dalji razvoj i unapređenje investicionih ulaganja. Jedno od značajnih u tom domenu je pitanje ugovaranja novih projekata, koje stranim investitorima mora garantovati sigurnost i primenljivost instituta uobičajenih u savremenoj trgovinskoj praksi. Upravo zbog toga što su glavni investitori industrijskog razvoja i dalje razvijene zemlje (Popovčić Ančić \& Đenić, 2011).

Široka primenljivost opštih uslova ugovora koje je objavio FIDIC zasnovana je na njihovoj dugogodišnjoj primeni na polju međunarodnog građenja, upravo od strane razvijenih industrijskih zemalja. U prilog tome navodimo činjenicu da nakon Drugog svetskog rata, kada nastupa građevinska ekspanzija na globalnom nivou, nisu postojali dovoljno dobri opšti uslovi za izvođenje radova i vršenje usluga u građevinarstvu, koji bi unifikacijom pravila na međunarodnim građevinskim poslovima poštedeli učesnike stalnog prilagođavanja lokalnim zakonima i praksi. Nakon raspada SSSR-a dolazi do nagle primene ovih uslova i na tom području, pa je zahvaljujući takvoj političkoj promeni nastupio značajni porast njihove primene. 
Pored uobičajenih poslova građenja, sastavnim delom građevinskog posla smatra se isporuka i montaža investicione opreme, kao i drugi specifični poslovi koji prethode izgradnji, a koji se mogu odnositi na pripremne i istražne radove, projektovanje, nadzor nad izvođenjem radova i sl. (Nikčević \& Nikčević, 2011). S tim u vezi, FIDIC je objavio više različitih vrsta opštih uslova ugovora u domenu građevinarstva, u nekoliko izdanja, koji se bave različitom vrstom poslova u sferi građevinarstva (izvođenje građevinskih radova, izvođenje elektro-mašinskih radova, projektovanje i građenje po sistemu ključ u ruke, forme ugovora i sl.). Svakako, bez obzira na prirodu posla koji regulišu pojedinačni opšti uslovi, pitanja opšteg karaktera (način rešavanja sporova, način plaćanja, primena domaćeg zakona, i sl.), u većini izdanja regulisana su vrlo slično. Takav je slučaj sa izdanjima koja su objavljena 1999. godine.

\section{NASTANAK I RAZVOJ FIDIC-A}

Prvi FIDIC-ovi opšti uslovi ugovora nastali su 1957. godine, u vreme velike obnove koja je nastupila nakon Drugog svetskog rata. Razlozi njihovog nastanka se u najvećoj meri vezuju za potrebu građevinskih kompanija koje su učestvovale u međunarodnim poslovima građenja da kroz unapred definisane i opšteprihvaćene standarde i pravila koja bi važila širom sveta, pojednostave proceduru učešća u građevinskim projektima i na taj način izbegnu stalno prilagođavanje lokalnim propisima i praksi. U tom smislu, ukratko se treba upoznati i sa razvojem organizacije FIDIC.

Međunarodna organizacija pod čijim okriljem nastaju ovi opšti uslovi ugovora, od samog osnivanja nosi francuski naziv "Fédération Internationale Des Ingénieurs Conseils", te otuda skraćenica FIDIC, što u prevodu na srpski jezik znači: "Međunarodna organizacija konsalting inženjera". FIDIC je osnovan 1913. godine u Ženevi, od strane tri države francuskog govornog područja, Belgije, Francuske i Švajcarske. Prevashodni cilj osnivanja bio je da u globalnoj svetskoj privredi, posebno u sektoru građevinarstva i industrije, zaživi oblik strukovnog, odnosno profesionalnog povezivanja, saradnje, intelektualne razmene, a radi zaštite profesionalnih interesa i stvaranja jedinstvenih standarda i prakse u oblasti konsaltinga i građevinarstva. U tome se, neosporno, i te kako uspelo. Posle gotovo četiri decenije postojanja, nagli porast građenja omogućio je FIDIC-u da zauzme dominantno mesto u građevinskoj industriji.

Danas, FIDIC predstavlja jednu od najznačajnijih profesionalnih organizacija u oblasti građevinarstva, sa jasno definisanim ciljevima i načelima rada. Etičnost, profesionalizam i fleksibilnost, osnovni su principi koji mogu dovesti do potpunog zadovoljenja klijenata i razvoja novih znanja (YU BILD, Znanje za stvaraoce). Aktivnosti FIDIC-a su: organizovanje seminara, debata i konferencija u cilju održavanja visokih etičkih standarda, kao i razvoj inženjerske profesije u svim zemljama širom sveta, uz opsežnu izdavačku delatnost.
FIDIC danas čini preko 75 članica-udruženja iz različitih država, koje broje preko 1.000 .000 profesionalaca (International Federation of Consulting Engineers).

\section{VRSTE FIDIC-OVIH OPŠTIH USLOVA UGOVORA}

FIDIC-ovi opšti uslovi ugovora koncipirani su sa idejom da se na globalnom nivou definišu i utvrde uniformna pravila koja bi sadržala uobičajene elemente građevinskog posla. Prednosti zaključivanja takvih standardnih, tipskih ugovora su višestruke: pojeftinjenje procesa zaključivanja ugovora, povećanje poverenja izvođača u ugovor, smanjenje broja nepredviđenih situacija i protivrečnosti, predviđanje rešenja za veliki broj spornih situacija koje se mogu pojaviti prilikom realizacije konkretnog projekta (Dabetić Trogrlić, 2010). S druge strane, mana ovih opštih uslova ugovora odnosi se na činjenicu da je reč o ugovorima po pristupu koji zahvaljujući mehanizmima licitacionih postupaka predviđaju da, konkretno izdanje FIDIC-a, predstavlja sastavni deo ugovorne dokumentacije, bez mogućnosti značajnih izmena ili dopune istih od strane potencijalnih ponuđača.

Tako su, nakon četiri decenije od osnivanja, 1957. godine objavljeni prvi FIDIC-ovi opšti uslovi ugovora:

1. "Conditions of contract (international) for works of civil engineering construction", odnosno "Opšti uslovi ugovora za građevinske radove” objavljeni su 1957. godine. Ovi uslovi su poznati i pod imenom "Crvena knjiga”, imajući u vidu boju njihovih korica. Crvena knjiga je menjana četiri puta u naredne četiri decenije;

2. "Conditions of contract (international) for electrical and mechanical works", odnosno "Opšti uslovi ugovora za izvođenje elektro-mašinskih radova”, poznatiji kao "Žuta knjiga” objavljeni su 1963. godine;

3. "Conditions of Contract for Design Build and Turnkey", odnosno "Opšti uslovi ugovora o projektovanju i građenju, po sistemu ključ u ruke”, poznatiji kao "Narandžasta knjiga" objavljeni su 1995. godine.

Posle dugogodišnje primene koja je dokazala značaj i ukazala na nedostatke, 1999. godine opšti uslovi su zamenjeni novim izdanjem koje je objavljeno u četiri knjige, i to:

1. "Conditions of contract for Construction for Building and Engeneering works designed by the Employer: First edition 1999", odnosno "Opšti uslovi ugovora za građevinske radove" koji su projektovani od strane naručioca, takođe poznata pod nazivom "Nova crvena knjiga";

2. "Conditions of Contract for Plant and Design-Build, For Electrical and Mechanical Plant and For Building and Engineering Works Designed by the Contractor: First edition 1999", odnosno "Opšti uslovi ugovora za projektovanje i izvođenje elektro-mašinskih radova i građevinskih radova projektovanih od strane izvođača", poznatija pod nazivom "Nova žuta knjiga"; 
3. "Conditions of Contract for EPC/Turnkey projects First edition 1999”, odnosno "Opšti uslovi ugovora za izvođenje radova po sistemu ključ u ruke” - poznata kao "Srebrna knjiga";

4. "The short form of Contract", odnosno "Kratka forma ugovora”, poznatija pod nazivom “Zelena knjiga”.

FIDIC je u poslednjih nekoliko godina proširio izdavački korpus raznoraznim vodičima i modelima ugovora. Tako su tokom 2003. godine objavljeni "FIDIC Guidelines for the Selection of Consultants". Prvi harmonizovani opšti uslovi ugovora međunarodnih finansijskih organizacija objavljeni su 2005. godine, odnosno "Multilateral Development Banks Harmonized Edition", koji se primenjuju kod projekata finansiranih od strane međunarodnih finansijskih organizacija, odnosno razvojnih banaka. Nova verzija je objavljena 2010. godine pod nazivom "Conditions of Contract for Construction: Multilateral Development Bank Harmonised Ed. Version 3”. Četvrto izdanje Bele knjige objavljeno je 2006. godine pod nazivom "Client/Consultant Model Services Agreement (White Book) $4^{\text {th }}$ Ed." (Vukmir, 2009). Zlatna knjiga, odnosno "DBO Contract: Conditions of Contract for Design, Build and Operate Projects ( $1^{\text {st }} \mathrm{Ed}$.)", objavljena je 2008. godine.

\section{NAČIN UGOVARANJA I PRAVNA PRIRODA}

Opšti uslovi poslovanja predstavljaju skup pravila, sadržanih u ugovoru ili aktu izvan njega, prethodno pripremljenih u pisanom obliku, od jedne strane, koje su pritom izvor ovlašćenja i obaveza za obe strane (Babić, 2008). Oni se razlikuju od adhezionih ugovora, jer kad su drugoj strani ponuđeni opšti uslovi poslovanja, ona može slobodno da predloži njihove izmene i dopune, tj. pogodbe koje joj više odgovaraju (Babić, 2008).

U smislu navedenog, FIDIC-ovi opšti uslovi ugovora su oni koji su kao takvi objavljeni od strane FIDIC-a, kao nezavisne, stručne i profesionalne organizacije. Njihovom primenom se uređuju odnosi dveju strana, koje sa FIDIC-om (kao profesionalnim udruženjem, organizacijom) ne stoje ni u kakvoj pravnoj vezi, te ih predlaže naručilac posla. Međutim, njihova sadržina najčešće nije u potpunosti adekvatna specifičnim okolnostima jednog projekta. Zato su opšti uslovi ugovora, kao što smo to ranije naveli, praćeni posebnim uslovima "particular conditions/special conditions" kojim se opšti uslovi menjaju, prilagođavaju ili isključuju. Tehnika izmena koje sadrže "particular conditions", odnosno posebni uslovi je takva da se u tim posebnim uslovima navede član iz opštih uslova koji se menja, a zatim i vrsta promene, tako da bude izvesno da li je priroda promene takva da se član briše, ili da se menja samo jedan deo, npr. "Sub Clause 4.1. shall be amended as follows...", "Clause 17 shall be deleted in its entirety" i sl.

Način ugovoranja FIDIC-ovih opštih uslova ugovora je jednostavan. Potrebno je da ugovorne strane njihovu primenu predvide ugovorom i u tom smislu oni su, najčešće, predviđe- ni već kao sastavni deo licitacione (tenderske) dokumentacije. Ugovor koji zaključuju ugovorne strane predstavlja obrazac sadržan u opštim uslovima konkretnog FIDIC-a, i to je kratak dokument koji nosi naziv "Contract agreement". Njime se imenuju ugovorne strane, ukratko opisuje predmet posla, naziv projekta, tip cene i njen iznos, uz detaljno navođenje svih dokumenata koji predstavljaju priloge uz ugovor, a kojim se pojedina pitanja detaljno uređuju. Među tim prilozima se mogu nalaziti: ponuda, FIDIC-ovi opšti uslovi ugovora, zatim posebni uslovi ugovora (kojim ugovorne strane prilagođavaju opšte uslove konkretnom projektu), projekat, specifikacije i druga dokumentacija koju ugovorne strane definišu, s tim da tehnikom nabrajanja bude definisana važnost tih dokumenata.

Pomenuti prilozi se, u duhu FIDIC-ove terminologije, definišu na sledeći način:

- "Letter of acceptance" - dokument kojim naručilac posla formalno obaveštava ponuđača da je njegova ponuda prihvaćena; u ovom dokumentu mogu biti sadržane i odredbe koje ponuđača ovlašćuju da počne sa pojedinim radovima, pripremama i sl.

- "The Bid" - ponuda,

- "Particular Conditions" - posebni uslovi ugovora, kojim se FIDIC-ovi opšti uslovi menjaju, tako da se prilagode specifičnostima posla, lokalnoj praksi, zakonskoj regulativi i sl. Primetićemo da su oni po svojoj važnosti ispred FIDIC-ovih opštih uslova ugovora, što je i logično, s obzirom da oni imaju karakter posebnih odredbi u odnosu na opšte uslove.

- "FIDIC General Conditions", "Drawings" - crteži, projekti,

- "Bill of quantities" - predmer i predračun radova,

- "Price Schedule" - pregled cena,

- "Form of guaranties" - forme garancija koje je izvođač radova (ili naruilac) dužan da dostavi drugoj ugovornoj strani,

- “Technical Data”.

Dakle, kao što smo rekli, sva navedena dokumentacija predstavlja sastavni deo ugovora (Contract agreement), ali je celokupan set tih dokumenata, uključujući i "Contract agreement" obuhvaćen terminom "Contract”. Pomenute definicije, i niz drugih, date su u opštim uslovima.

Po kriterijumu izvora, FIDIC-ovi opšti uslovi spadaju u norme međunarodnog autonomnog prava, s obzirom da nastaju pod okriljem udruženja, odnosno organizacije autonomnog karaktera. Rasprostranjenost ovih opštih uslova navela je pojedine autore da ih smatraju normama „lex mercatoria“ u domenu prava građenja (Vukmir, 2009), ali je takav pristup neosnovan. Prvi razlog se vezuje za činjenicu da se primenjuju samo kad ih strane ugovore, a veliki je broj značajnih projekata kod kojih primena ovih opštih uslova nije predviđena. Drugi, ali još važniji razlog se vezuje za činjenicu postojanja velikog broja imperativnih normi lokalnih zakonodavstava, sa kojima odredbe FIDIC-ovih opštih uslova nisu uvek u skladu. 


\section{RAZLIKE IZMEĐU NOVIH I STARIH IZDANJA FIDIC-OVIH OPŠTIH USLOVA}

Razlike između novih i starih izdanja zaslužuju poseban osvrt. Ali pre nego što ukažemo na te razlike, treba prokomentarisati i zvanični naziv prvih FIDIC-ovih izdanja, odnosno Crvene i Žute knjige, koje u naslovu sadrže pojam "international", iako su ove knjige bile ponajmanje "međunarodne". Naime, prvi FIDIC-ovi opšti uslovi su u celosti preuzeti iz britanskih opštih uslova ugovora "ICO Conditions of Contract", uz najčešće isticano objašnjenje da su ovi uslovi tada bili uveliko rasprostranjeni. Smatra se da je posredi britanski uticaj na veliki broj zemalja koje su bile primamljive građevinskoj industriji (npr. Afrika), a koje su $\mathrm{u}$ prethodnom istorijskom periodu bile britanske kolonije. Svakako, ova okolnost nije bila smetnja da FIDIC-ovi opšti uslovi ugovora steknu popularnost i široku primenu, čak i u onim zemljama u kojima postoji kontinentalni pravni sistem, što između ostalog govori o opštem uticaju britanskog prava na međunarodno pravo u oblasti građevinarstva. Sve kasnije promene Crvene knjige, koje su objavljene u trećem izdanju 1977. godine, i dalje su se u značajnoj meri kretale u okvirima britanskog prava (Vukmir, 2009). Tek kod izmene koja je izvršena 1987. godine, iz uobičajenog naziva se izuzima reč "međunarodni”, što je opet bilo manje važno, s obzirom da su ovi uslovi u svojoj suštini ostali pod predominantnim uticajem anglosaksonskog prava.

Razlike između novih i starih FIDIC-ovih knjiga, pre svega se uočavaju u pogledu načina njihovog razlikovanja, koji je popularno vezan za boju njihovih korica. $S$ tim u vezi, radi lakšeg razlikovanja, boje prvih FDIC-ovih knjiga su se vezivale za neke od radova na koje se te knjige odnose. Tako su opšti uslovi ugovora za izvođenje građevinskih radova, bili objavljeni u Crvenoj knjizi, opšti uslovi ugovora o izvođenju elektro-mašinskih radova u tzv. Žutoj knjizi, dok je Narandžasta knjiga bila predviđena za radove koji se izvode po sistemu "ključ u ruke". Kasnije, nakon objavljivanja novih FIDIC-ovih uslova iz 1999. godine, kriterijum razlikovanja po bojama će se promeniti i to tako da se boje više ne određuju prema kriterijumu vrste radova, već prema tome ko je izradio projekat za konkretan posao. Tako, u novoj Crvenoj knjizi projekat izrađuje naručilac posla, u novoj Žutoj knjizi projekat izrađuje izvođač, dok se u Srebrnoj knjizi ovo pitanje i ne postavlja, s obzirom na činjenicu da se radi o izvođenju radova po sistemu "ključ u ruke", tako da sve radove, uključujući i projektovanje, obavljaju izvođači.

Najvažnija razlika, kojoj treba posvetiti najviše pažnje, odnosi se na ulogu "inženjera”, koji između ostalog predstavlja nadzorni organ, ali sa dodatnim, daleko većim ovlašćenjima u odnosu na nadzorni organ koji je utvrđen našim Zakonom o planiranju i izgradnji, što, uz materiju rešavanja sporova, otvara i suštinsko pitanje ovog rada, a to je primena FIDIC-ovih opštih uslova na domaćem tržištu.

\section{PRIMENA FIDIC-OVIH OPŠTIH USLOVA UGOVORA NA DOMAĆEM TRŽIŠTU}

Prilikom primene ovih opštih uslova ugovora na domaćim projektima, posebnu pažnju treba obratiti na odnos imperativnih odredbi domaćeg zakonodavstva i odredbi FIDICovih opštih uslova, koje međusobno treba uskladiti.

Naime, uloga "inženjera" je različito koncipirana u prvim FIDIC-ovim opštim uslovima i onim koji su objavljivani kasnije, a isto tako i u odnosu na nadzor koji se obavezno sprovodi prema odredbama Zakona o planiranju i izgradnji Republike Srbije. Prema prvobitnoj Crvenoj i Žutoj knjizi “inženjer" je imao ulogu "nezavisnog" stručnjaka koji vrši nadzor, prati realizaciju projekta i usaglašenosti izvedenih radova sa tehničkom dokumentacijom. Pored toga, "inženjeru” je bilo dato i jedno specifično ovlašćenje zbog kojeg je i u teoriji i u praksi često nazivan "kvazi arbitrom" (Paunović, 1993). Zbog toga što je, u slučaju spora između naručioca i izvođača, "inženjer" predstavljao instancu koja prethodi arbitražnom postupku. Njegova ovlašćenja su omogućavala da rešava sporove, utvrđuje okolnosti i činjenice, da tumači odredbe ugovora i donosi privremene odluke, koje su obavezivale i jednu i drugu stranu, sve do konačnog donošenja odluke u arbitražnom postupku.

Glavna primedba ovakvom pristupu odnosila se na činjenicu da je "inženjera" imenovao i plaćao naručilac, čime se njegova objektivnost i nepristrasnost u donošenju odluka, odnosno nezavisnost od ugovornih strana dovodila u pitanje. Zato su, pod uticajem opravdanih kritika, u izdanju koje je objavljeno 1995. godine (Narandžasta knjiga), dotadašnji koncept i uloga "inženjera” izmenjeni. U tom pogledu predviđeno je da ovlašćenja „inženjera“ ne budu drastično promenjena u pogledu nadzora nad izvođenjem radova, dok će se znatno ublažiti u pogledu rešavanja sporova. Naime, između "inženjera” kao prve, i arbitraže kao druge instance za rešavanje sporova, uvodi se još jedan postupak koji je popularno nazvan "DAB" (Dispute Adjudiction Board). Takav koncept je prihvaćen i u svim izdanjima FIDIC-ovih opštih uslova ugovora koji su objavljeni 1999. godine.

Iz izloženog koncepta se može uočiti da je uloga "inženjera”, onako kako je to bilo predviđeno u prvim FIDIC-ovim knjigama, bila značajna, jer je bio prva instanca u rešavanju svih sporova, bilo pravne, bilo tehničke prirode. Razlog za takav pristup nije u potpunosti jasan, ali se u najvećoj meri vezuje za ideju brzog i efikasnog rešavanja sporova. Tačnije, ova uloga "inženjera” je zamišljena tako da on "u hodu” rešava sve one sporne situacije koje mogu dovesti do usporavanja projekta. Ali, ukoliko se uzme u obzir da je njegova nezavisnost i nepristrasnost bila često dovedena u pitanje, zbog redovne naklonosti prema naručiocu koji ga imenuje i plaća, jasno je što je već 1995. godine, ovaj koncept izmenjen.

Noviji FIDIC-ovi opšti uslovi ugovora, iz 1995. godine, su izmenili ovaj koncept, delimično u pogledu ovlašćenja 
“inženjera”, delimično u materiji rešavanja sporova. Svakako, pre nego što se osvrnemo na materiju rešavanja sporova, primena ovih opštih uslova na domaćem tržištu, iziskuje posebnu pažnju kada se uloga “inženjera” stavi u kontekst nadzora nad izvođenjem radova koje predviđa domaće zakonodavstvo. "Prima facie" jasno se može uočiti da uloga "inženjera" ne može da se upodobi nadzornom organu koji je predviđen domaćim Zakonom o planiranju i izgradnji, kako zbog njegovih ovlašćenja da odlučuje o zahtevima i potraživanjima izvođača prema naručiocu, tako i zbog prirode celokupne uloge koju on ima tokom realizacije ugovora. Zato, kada se ugovara primena FIDIC-a u Srbiji, gotovo i nije moguće „inženjera“ podvesti pod instituciju nadzora nad izvođenjem radova, a da se pri tome ne prevaziđu ovlašćenja nadzornog organa koja on ima prema Zakonu o planiranju i izgradnji, ili da se pak ne umanje ona ovlašćenja koje „inženjer“ ima prema FIDICovim opštim uslovima bez kojih bi on izgubio ulogu koju mu je FIDIC dao. Zato se redovno, na domaćim projektima koji su zasnovani na FIDIC-ovim opštim uslovima, pojavljuju paralelne institucije nadzora, od kojih je jedan obavezan, u skladu sa odredbama Zakona o planiranju i izgradnji, dok je drugi “inženjer" ugovornog karaktera, i pojavljuje se u međusobnim odnosima ugovornih strana. Da bi se izbegle situacije u koje izvođač može zapasti usled naloga i ovlašćenja "inženjera" i nadzornog organa koji su kontradiktorni, neophodno je ugovoriti odredbu prema kojoj naručilac i izvođač regulišu svoje odnose povodom takvih naloga tako što nalozi nadzornog organa imaju prednost nad nalozima "inženjera", što je i logično, s obzirom da su oni kao takvi obavezni.

Kao što smo pomenuli, izmene u domenu “inženjera” koje su izvršene u izdanjima iz 1995. godine, odnosno 1999. godine, odrazile su se i na materiju rešavanja sporova. Celokupan postupak za rešavanje sporova sada je podeljen u tri faze. Kako o spornim pitanjima, u prvoj instanci i dalje odlučuje “inženjer”, uz kasniji postupak pred DAB-om i arbitražom, radilo bi se o trostepenom postupku. Tako, prema članu 20.1 svih opštih uslova iz 1999. godine, izvođač mora da se obrati “inženjeru”, između ostalog, i u vezi sa sledećim zahtevima:

\section{Zahtev za produžetak roka;}

2. Zahtev za dodatno plaćanje po bilo kom osnovu.

Kada u vezi sa ovim zahtevima “inženjer” donese svoju odluku, nezadovoljna strana ima mogućnost da se za zaštitu svojih prava obrati DAB-u. Tada DAB predstavlja drugostepeni organ. S druge strane, za ona sporna pitanja koja eventualno nisu u nadležnosti "inženjera” (iako je u praksi takvih pitanja malo), DAB bi predstavljao prvostepeni organ odlučivanja. Suština DAB-a se u najvećoj meri zasniva na ideji da je to nezavisan, stručan i fleksibilan organ koji će u što kraćem roku rešavati sporove, kako radovi ne bi bili obustavljeni. Time bi se, na neki način, napravio i svojevrsni "filter" za bespotrebne i suvišne sporove pred arbitražom ili drugim nadležnim organom, koji bi pored velikih troškova, oduzeli isuviše vremena. U tom cilju, ovaj postupak je dale- ko jeftiniji i jednostavniji u odnosu na arbitražu i vremenski ograničen. Ali se opravdano može postaviti pitanje njegove primenljivosti na domaćem tržištu, s obzirom na to da se radi o "gošćama” međunarodnog autonomnog prava. Problem nastaje kada se ugovorena dejstva DAB-a, odnosno njegovih odluka, ne poklapaju sa suštinskim statusom i kvalitetom tih odluka prema domaćem zakonodavstvu, jer u Republici Srbiji ne postoji adekvatna regulativa za ovaj postupak. DAB je ugovornog karaktera pa su pravila postupka pred DAB-om uređena sporazumom, odnosno opštim uslovima ugovora. Samim tim i efekti postupka pred DAB-om, nisu dalekosežni, jer odluka DAB-a može biti najsličnija vansudskom poravnanju. Time već zalazimo i u pitanje (ne)izvršnosti ovih odluka, što ugovornim stranama, ukoliko u odgovarajućem momentu ne pokrenu arbitražni postupak na način koji je definisan opštim uslovima, uskraćuje izvršnost ovih odluka koju naši zakoni ne poznaju kao takvu.

Pored navedenog, važno je istaći i da član 388. Zakona o obligacionim odnosima predviđa da se "zastarelost potraživanja prekida podizanjem tužbe ili bilo kojom drugom poveriočevom radnjom preduzetom protiv dužnika pred sudom, ili drugim nadležnim organom, u cilju utvrđivanja, obezbeđenja ili ostvarenja potraživanja”. U tom kontekstu, a kad se uzme u obzir da se DAB ne pokreće tužbom, ne predstavlja sudski postupak, da se DAB ne može podvesti ni pod drugi nadležni organ, dolazimo do zaključka da postupak pred DAB-om ne prekida zastarelost.

Rešavanje sporova se svakako iscrpljuje u arbitražnom postupku, kao poslednjoj instanci koju predviđa FIDIC, u svim svojim opštim uslovima ugovora. U tom smislu, za pokretanje arbitraže je neophodno ispunjenje određenih uslova, a tu se upravo vraćamo na pitanje DAB-a i „inženjera“, u kontekstu FIDIC-ovih opštih uslova ugovora i domaće regulative ovih instituta. Naime, da bi postupak pred arbitražom bio pokrenut, potrebno je da ugovorna strana, koja je nezadovoljna odlukom DAB-a, u tačno utvrđenom roku izjavi svoje nezadovoljstvo takvom odlukom (notice of disatisfaction), a zatim i nameru da pokrene arbitražni postupak (intention of the Party to commence arbitration). Dakle, ukoliko su ugovorne strane zadovoljne odlukom DAB-a, nakon proteka određenog roka (u opštim uslovima FIDIC-a to je rok od 56 dana, ali se posebnim uslovima može menjati), odluke DAB-a postaju "final and binding", što, kad se uzme u obzir prethodno rečeno o prepoznavanju DAB-a u domaćoj pravnoj regulativi, nije primenljivo u domaćoj praksi. Svakako, izbor arbitražne institucije, za slučaj da do arbitražnog postupka dođe, zavisi od ugovornih strana, koje već u ugovoru definišu arbitražnu instituciju (ako se ugovorne strane opredele za institucionalnu arbitražu), odnosno ad hoc arbitražu. FIDIC u opštim uslovima ugovora predlaže arbitražu pri Međunarodnoj trgovinskoj komori u Parizu (ICC Arbitration Court, Paris), koja kao i sve druge prestižne međunarodne arbitražne institucije, postupa po unapred pripremljenim pravilima postupka. Pravilnici koje donose stalne međunarodne trgovinske arbitraže, 
po pravilu, detaljno regulišu sva pitanja od značaja za jedan arbitražni postupak, počev od organizacije i nadležnosti arbitraže, preko konstituisanja arbitražnog tribunala i pravila postupka, sve do arbitražne odluke i troškova arbitraže. Ovi pravilnici su u najvećoj meri prihvatljivi za stranke zbog toga što pravila koja su u njima sadržana počivaju na običajima i opšteprihvaćenim principima arbitražnog prava, pravnim standardima, uslovima poslovanja i drugim ustaljenim i racionalnim postupcima poslovnih ljudi u međunarodnom trgovinskom prometu (Jovičić, 2008).

\section{ZAKLJUČAK}

FIDIC-ovi opšti uslovi ugovora imaju zavidan značaj na međunarodnom poslovnom planu, pre svega zbog dugogodišnje primene, a zatim i zbog dobro osmišljenog ugovornog koncepta za realizaciju građevinskih investicionih projekata. Tome doprinosi i svakodnevno unapređenje FIDIC-ovih opštih uslova kroz međunarodne kongrese, seminare i različite primene u praksi koju ova organizacija nudi.

Instituti koje predviđa FIDIC nastali su primenom njegovih opštih uslova širom sveta, pa je jasno zašto se u njihovom korpusu nalaze i oni instituti koji nisu poznati našem pravu, što nameće potrebu njihovog blagovremenog usklađivanja (dakle, već u postupku pregovora) sa domaćim imperativnim propisima, onda kada se ugovara njihova primena.

Tu se pre svega misli na ulogu „inženjera“ koji prema ovim uslovima ima daleko šira ovlašćenja od onih koja su data nadzornom organu predviđenom Zakonom o planiranju i izgradnji.

Isto važi i za materiju rešavanja sporova, gde postupak pred DAB-om, koji nastupa nakon donošenja odluke od strane "inženjera", a prethodi arbitražnom postupku, nije regulisan u domaćem zakonodavstvu. Odluke ovog tela nisu izvršne, ne prekidaju zastarelost, ali je postupak pred DAB-om obavezan u ugovornom smislu, što faktički može blokirati rešavanje sporova isticanjem prigovora nenadležnosti ili preuranjenosti tužbenog zahteva (onda kada se neka ugovorna strana umesto DAB-u obrati arbitraži). Zato ove odredbe treba upodobiti domaćem zakonodavstvu i isključiti ih u onoj meri u kojoj su one neprimenljive, a na način kako je to u radu pojašnjeno.

\section{LITERATURA}

Babić, I. (2008). Uvod u građansko pravo i stvarno pravo. Beograd: Projuris.

Dabetić Trogrlić, V. (2010). Neopravdano normiranje ograničenja autonomije volje kod ugovora o građenju sa posebnom odredbom „ključ u ruke“. Sinergija - VI naučni skup, 19.03.2010., Bijeljina. Univerzitet Sinergija, 443-453.

International Federation of Consulting Engineers. (1999). FIDIC's selection of contracts and agreements. Preuzeto 17.11.2016. sa http://www1.fidic.org/bookshop/default_contracts. asp\#collection

Jovičić, K. (2008). Međunarodna trgovinska arbitraža, Strani pravni zivot, 3/2008, 99-121

Nikčević, I., \& Nikčević, J. (2011) Ustupanje izvođenja radova kod ugovora o građenju. Singidunum revija, 8 (1), 265-276.

Paunović, M. (1993). Pred-arbitražno rešavanje sporova. Pravo $i$ privreda, 31(1-2), 5-10.

Popovčić Avrić, S., \& Đenić, M. (2011). Strane direktne investicije kao dinamički faktor svetske privrede. Singidunum revija, 8(1), 197-206.

Službeni glasnik RS. (2011). Zakon o planiranju i izgradnji. Službeni glasnik RS br. 72/09, 81/09 - ispr., 64/10 odluka US i $24 / 11$

Službeni list SFRJ. (1989). Zakon o obligacionim odnosima, Službeni list SFRJ, br. 29/78, 39/85, 45/89 - odluka USJ i 57/89, Službeni list SRJ, br. 31/93 i Službeni list SCG, br. 1/2003

Unković, M., \& Kordić, N. (2011). Mogućnosti Srbije za privlačenje stranih direktnih ulaganja. Singidunum revija, 8(1), 163-177.

Vukmir, B. (2009). Ugovori o građenju i uslugama savjetodavnih inžinjera. Zagreb: RRiF.

YU Build. (2008). Znanje za stvaraoce. Preuzeto 29.10.2016. sa http://www.inwestserbia.com/Prilozi/PrezentacijaFIDIC.pdf

\section{FIDIC'S GENERAL CONDITIONS OF CONTRACT AND THEIR USE IN DOMESTIC MARKET}

\begin{abstract}
:
Considering the fact that since the middle of the last century there has been almost no significant construction enterprise where contractual relationships have not been regulated by FIDIC's general conditions of contract, it is clear that the long-term application of these general conditions has proved their widespread acceptance and importance. The reasons for this could be sought in the field of many relations they govern, either of technical, legal or commercial nature, which allows project participants to adopt the "developed" relationship of mutual rights and obligations. Therefore, the paper contains an analysis of the development of FIDIC general conditions of contract, with special emphasis on their application in the domestic market.
\end{abstract}

\section{Keywords:}

general conditions,

engineer,

resolve litigations,

arbitration. 